\title{
STUDY OF THE EFFECTS OF ETHANOL AS AN ADDITIVE WITH A BLEND OF POULTRY LITTER BIODIESEL AND ALUMINA NANOPARTICLES ON A DIESEL ENGINE
}

\author{
RAMESHA D K, NISHAD RAJMALWAR, T SREEHARSHA VARMA \\ Department of Mechanical Engineering, University Visvesvaraya College of Engineering, Bangalore University, \\ Bangalore, Karnataka, India-560001, dkramesha@bub.ernet.in
}

\section{MRITHYUNAJAYA SWAMY K M}

Department of Mechanical Engineering, Vemana Institute of Technology, Visvesvaraya Technological University, Bangalore, Karnataka, India

\section{ABSTRACT}

With the increasing population and rise in industrialization, the demand for petroleum reserves is increasing almost daily. This is causing depletion of the non-renewable energy resources. This work aims to find an alternative fuel for diesel engines. The use of poultry litter oil biodiesel obtained from poultry industry waste, which is a non-edible source for biodiesel, is very encouraging as an alternative fuel for diesel engines. The aim of this study is to observe and maximize the performance of poultry litter oil biodiesel by adding alumina nanoparticles and ethanol. The biodiesel is prepared with acid and the base catalysed transesterification of poultry litter oil with methanol using concentrated sulphuric acid and potassium hydroxide as catalysts. The experimentation is carried out on a $\mathrm{Cl}$ engine with three different blends - B20 biodiesel blend, B20 biodiesel blend with $30 \mathrm{mg} / \mathrm{L}$ alumina nanoparticles, and B20 biodiesel blend with $30 \mathrm{mg} / \mathrm{L}$ alumina nanoparticles and $15 \mathrm{ml} / \mathrm{L}$ ethanol. The performance, combustion and emission characteristics of all three blends are compared with neat diesel. The results of the experiment show that ethanol as an additive improves the combustion and performance characteristics. It increases the brake thermal efficiency and peak cylinder pressure. It also reduces $\mathrm{CO}$ and UBHC emissions and there is a marginal increase in $\mathrm{NO}_{x}$ emissions as compared to neat diesel.

KEYWORDS: DIESEL ENGINE; POULTRY LITTER OIL METHYL ESTER; BIODIESEL; ALUMINA NANOPARTICLES;

TRANSESTERIFICATION; ETHANOL; PERFORMANCE; COMBUSTION; EMISSION.

\section{SHRNUTI}

S rostoucím počtem obyvatel a nárůstem industrializace se den za dnem zvyšuje poptávka po ropných rezervách. To způsobuje vyčerpávání neobnovitelných zdrojů energie. Tato práce si klade za cíl nalézt alternativní palivo pro dieselové motory. Použití bionafty získané z oleje z použité podestýlky z chovů drůbeže, která představuje nekonzumovatelný zdroj pro výrobu bionafty jako alternativní palivo pro dieselové motory, je velmi slibné. Cílem této studie je pozorovat a maximalizovat výkon bionafty z oleje z použité drůbeží podestýlky přidáním nanočástic oxidu hlinitého a etanolu. Bionafta je pripravována kyselinou a zásadou katalyzovanou transesterifikací oleje z použité drůbeži podestýlky a metanolem, kde jsou jako katalyzátory použity koncentrovaná kyselina sírová resp. draselný louh. Experimentace se provádí na vznětovém motoru s třemi různými druhy směsi - směs bionafty B20, směs bionafty B20 s $30 \mathrm{mg} / \mathrm{L}$ nanočástic oxidu hlinitého a směs bionafty B20 s $30 \mathrm{mg} / \mathrm{L}$ nanočástic oxidu hlinitého a $15 \mathrm{ml} / \mathrm{L}$ etanolu. Parametry výkonu, spalování a emisí všech tří směsí jsou srovnávány dieselovým palivem (naftou) bez př́sad. Výsledky experimentu ukazují, že etanol jako aditivum zlepšuje parametry spalování a výkonu. Zvyšuje brzdnou tepelnou účinnost a maximální tlak ve válci. Dále snižuje emise $\mathrm{CO}$ a nespálených uhlovodíků, přičemž je zde marginální zvýšení emisí $\mathrm{NO}_{\mathrm{x}}$ oproti naftě bez prísad.

KLIČCVÁ SLOVA: DIESELOVÝ MOTOR; METYLESTER OLEJE Z POUŽITÉ PODESTÝLKY DRŮBEŽE; BIODIESEL (BIONAFTA); NANOČÁSTICE OXIDU HLINITÉHO; TRANSESTERIFIKACE; ETANOL; VÝKON; SPALOVÁNÍ; EMISE. 


\section{INTRODUCTION}

Conventional fossil fuels cause environmental pollution and with demand for them ever increasing, they are being depleted at a fast pace. This situation necessitates paying greater attention to alternative fuels from natural resources, such as biodiesel and ethanol-biodiesel blends. Both biodiesel and ethanol can be synthesized from feedstock, which is a renewable resource. The carbon in the biodiesel comes from the $\mathrm{CO}_{2}$ present in the air, so the $\mathrm{CO}_{2}$ engine emissions when running on biodiesel overall add much less to global warming compared to fossil fuels. Efforts have been made to replace petroleum-based fuels with as much biofuel as possible because biodiesel by itself cannot be entirely used as a fuel [13] (Xiaoyan Shi et al. 2006). Biodiesel can be produced using the process of transesterification of vegetable/ animal oil or fat with a short-chain alcohol like methanol or ethanol. The reaction gives mono-alkyl esters which can be used as biodiesel. Neat oil cannot be used as a fuel mainly due to its high viscosity $\left(28-40 \mathrm{~mm}^{2} / \mathrm{s}\right)$, which leads to deposition of carbon particles in the injector in a $\mathrm{Cl}$ engine. This causes poorer atomization of fuel particles into the combustion chamber [2] (Darunde Dhiraj S. et al. 2012). Since neat vegetable/animal oil or fat cannot be used as a fuel, transesterification is carried out to reduce the viscosity. Transesterification is the reaction between a triglyceride molecule (found in vegetable oil or animal fat) and excess alcohol in the presence of a catalyst, such as $\mathrm{KOH}$, $\mathrm{NaOH}$ etc., to give methyl esters and glycerin as a by-product [11] (Sri Harsha Tirumala et al. 2012). The process occurs in several reversible steps where the triglyceride is converted to diglyceride, which is further converted to monoglyceride. These monoglycerides are then converted to esters and glycerol. The esters can be separated from glycerol using a separating funnel due to their density difference. In our experiment, the ester is called Poultry Litter Oil Methyl Ester [3] (Dr. Sadhik B. J. et al. 2012). At present, diesel fuel additives are used to lower the particulate emissions and enhance fuel characteristics such as oxidation rate. Additives also help to reduce emissions. One such additive are nanoparticles, which are pre-dissolved in the fuel and help increase the efficiency of the fuel and completion of the combustion process to reduce emissions of various harmful gases and particulate matter [8] (Nithin Samuel et al. 2015). With Aluminium oxide nanoparticles as an additive, an increase in brake thermal efficiency and a reduction in emissions were observed. Also, to increase the overall performance, combustion and emission characteristics of the engine, nanoparticles are the most suitable additive [9] (S.P. Venkatesan et al. 2015). To further improve the performance of the engine, the potential use of biodiesel with an ethanol blend was investigated. Ethanol improves the flow property of the fuel and helps ensure better atomization. It enhances the oxygen content of the fuel to help reduce emissions. The potential of poultry litter biodiesel with a blend of ethanol as a renewable energy resource is presented in this paper.

\section{TRANSESTERIFICATION}

\subsection{ESTERIFICATION SETUP}

The oil used for biodiesel production was non-edible raw poultry litter oil. Production was carried out using a laboratory setup. The setup consisted of beakers, flasks, a thermometer and a magnetic stirrer with temperature control and adjustable stirring speed. The properties of diesel fuel and PLOME are listed according to ASTM standards in Table 4. The acid value of raw oil had been calculated using a standard titrimetric method as per European standard EN14104. A conical flask was used as a laboratory scale reactor to carry out the transesterification process. The magnetic stirrer consisted of a heating coil with adjustable temperature. The flask was kept on the stirrer and the mixture was heated. The temperature for the reaction was maintained at $50-60^{\circ} \mathrm{C}$ and the mixture was stirred at constant speed at all times. The esterification process was carried out in two steps since the oil viscosity was high.

\subsubsection{ACID CATALYSED TRANSESTERIFICATION}

Acid transesterification was carried out by pouring 1 litre of raw poultry oil into the conical flask and heating it to a temperature of $50^{\circ} \mathrm{C}$. Once the oil reached this constant temperature, $500 \mathrm{ml}$ of methanol was added and stirred for a few minutes. $10 \mathrm{ml}$ of concentrated sulphuric acid was added to the mixture. This final mixture was maintained at a temperature of $50^{\circ} \mathrm{C}$ and stirred for 45 minutes at atmospheric pressure. The flask was removed from the stirrer and the mixture was allowed to settle. Two layers separate out and were visible to the naked eye. The layers were separated using a separating funnel. The top layer consisted of excess methanol, sulphuric acid and light impurities, which were removed. The lower layer was poured into a different flask for the next step of experimentation.

\subsubsection{BASE CATALYSED TRANSESTERIFICATION}

The final product from the first experimental setup of the acid catalysed process was used for alkaline esterification. The product was again heated to a temperature of $50^{\circ} \mathrm{C}$ in the flask. Meanwhile, $0.24 \mathrm{~g}$ of $\mathrm{KOH}$ was added to $100 \mathrm{ml}$ of methanol in a beaker and thoroughly dissolved. This mixture was poured into the flask and heated at $50^{\circ} \mathrm{C}$ for 45 minutes. Once the heating was complete, the mixture was allowed to cool down. Again, layer separation was noticeable. This time the lower layer consisted of glycerol and impurities, which were discarded. The top layer 
TABLE 1: Fuel properties

TABULKA 1: Vlastnosti paliv

\begin{tabular}{|c|c|c|c|c|c|c|}
\hline $\begin{array}{l}\text { SI. } \\
\text { No. }\end{array}$ & Property & $\begin{array}{l}\text { ASTM } \\
\text { Method }\end{array}$ & $\begin{array}{l}\text { Limits } \\
\text { (B100) }\end{array}$ & Units & Diesel & PLOME \\
\hline 1 & Colour & - & - & - & Orange & $\begin{array}{l}\text { Pale } \\
\text { Yellow }\end{array}$ \\
\hline 2 & Density & D941 & - & $\mathrm{kg} / \mathrm{m}^{3}$ & 850 & 737 \\
\hline 3 & $\begin{array}{l}\text { Kinematic } \\
\text { viscosity, } \\
40^{\circ} \mathrm{C}\end{array}$ & D445 & $1.9-6$ & $\mathrm{~mm}^{2} / \mathrm{s}$ & 2.5 & 5.48 \\
\hline 4 & Calorific value & D2015 & - & $\mathrm{kJ} / \mathrm{kg}$ & 42000 & 29000 \\
\hline 5 & Fire point & D93 & - & ${ }^{\circ} \mathrm{C}$ & 56 & 178 \\
\hline 6 & Flash point & D93 & $130 \mathrm{~min}$. & ${ }^{\circ} \mathrm{C}$ & 50 & 154 \\
\hline 7 & Cetane index & D613 & $47 \mathrm{~min}$. & - & 55 & 61 \\
\hline
\end{tabular}

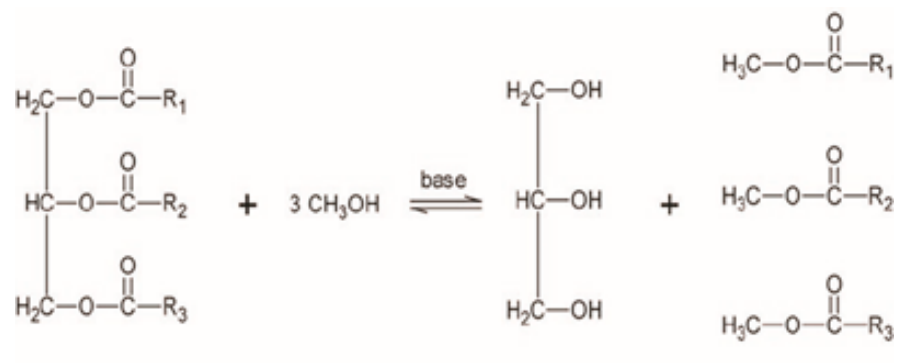

Triglyceride Methanol Glycerol Methyl Esters

FIGURE 1: Mechanism of the transesterification process OBRÁZEK 1: Mechanismus procesu transesterifikace

was the methyl ester, which was separated using the separating funnel. This ester contained some impurities and was therefore water washed. Hot distilled water, $10 \%$ by volume, was sprayed over the surface of the ester and gently stirred. The water carried impurities and settled down at the bottom of the flask. The top layer (yellow colour) was the biodiesel which was separated and collected.

\subsubsection{PREPARATION OF BLEND}

B20PLOME was prepared by mixing $20 \%$ by volume biodiesel with $80 \%$ by volume diesel in a beaker and stirring it for 15 minutes at constant room temperature. B20PLOME30A was prepared by adding $30 \mathrm{mg}$ of alumina nanoparticles to 1 litre of B20PLOME biodiesel blend. B20PIOME30A15E was prepared by adding $15 \mathrm{ml} / \mathrm{l}$ of pure ethanol to the B20PLOME30A blend.

\subsubsection{ADDITION OF ALUMINA NANOPARTICLES}

The nanoparticles were added to B20PLOME biodiesel fuel with the help of an ultrasonicator at a frequency of $24 \mathrm{kHz}$. The process was carried out for 30 minutes. The mass fraction of the nanoparticles was $30 \mathrm{mg} / \mathrm{l}$. It was weighed using an electronic
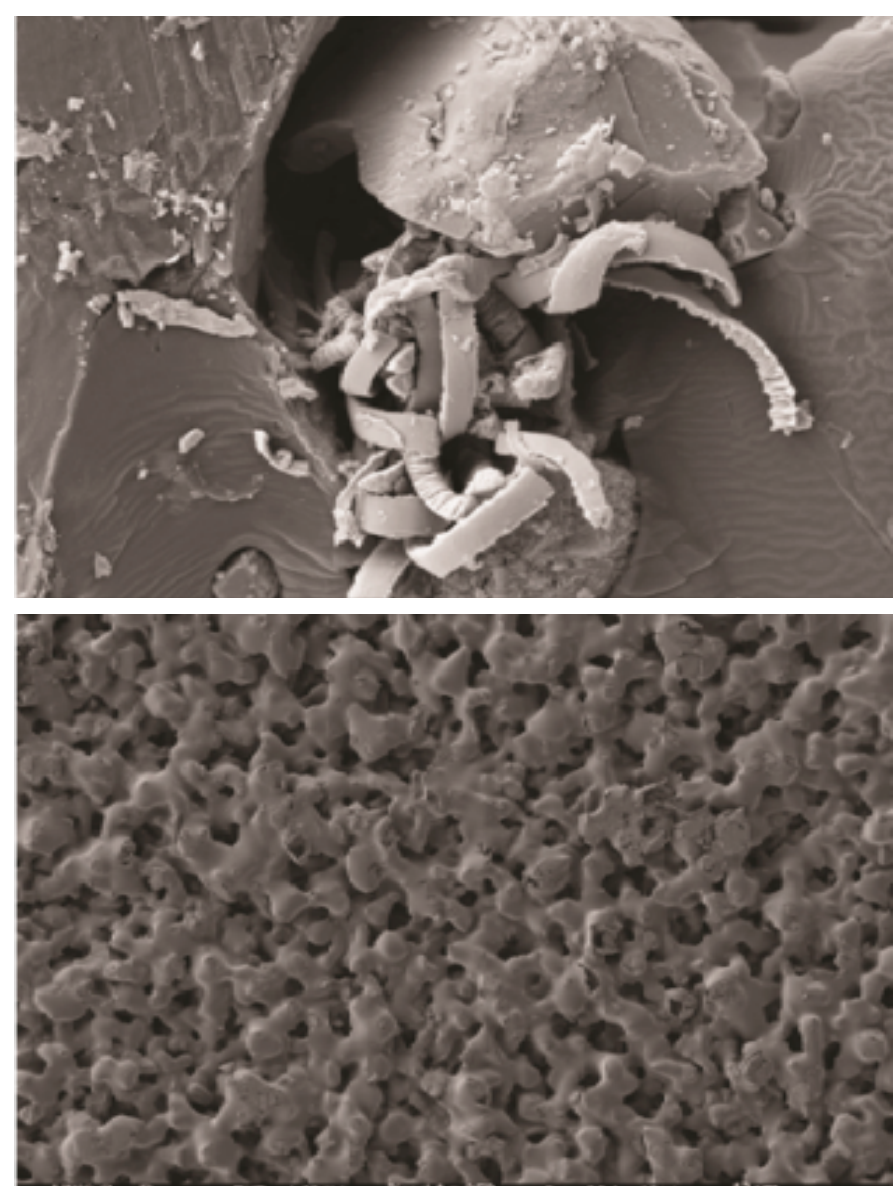

FIGURE 2: Transmission electron microscope image of alumina nanoparticle OBRÁZEK 2: Obrázek elektronového mikroskopu hliníkových nanočástic

weighing machine with readability of $1 \mathrm{mg}$. The ultrasonication technique disperses the nanoparticles in a base fluid, which in this case was the biodiesel fuel. It is the best suited technique since it prevents the aggregation of nanoparticles by agitating the particles using pulsating ultrasonic frequencies. The alumina nanoparticle specification is shown in Table 1. Figure 2 shows the morphology of alumina nanoparticles. Surfactants were added to lower the surface tension between the liquid fuel and solid nanoparticles in order to stabilize the nanoparticles.

\subsubsection{ADDITION OF ETHANOL}

Ethanol was added with a composition of $15 \mathrm{ml}$ of ethanol per litre of B20PLOME30A biodiesel fuel. The mixing process was carried out by constant stirring on the magnetic stirrer for 30 minutes without any heating, maintaining the mixture at room temperature. This final mixture is designated B20PLOME30A15E.

\section{ENGINE TEST}

The engine test was conducted on a single cylinder four-stroke diesel engine with injection timing of 23 degrees BTDC, injection pressure of $180,17.5: 1$ compression ratio and a speed 
TABLE 2: Specification of alumina nanoparticles

TABULKA 2: Vlastnosti hliníkových nanočástic

\begin{tabular}{|c|c|}
\hline Properties & Specification \\
\hline Chemical name & $\begin{array}{l}\text { Gamma Aluminium Oxide (Alumina, Al203) } \\
\text { Nanopowder, gamma phase, } 99.9 \%\end{array}$ \\
\hline Average particle size & $20-50 \mathrm{~nm}$ \\
\hline Appearance & White \\
\hline Melting point & $2045^{\circ} \mathrm{C}$ \\
\hline Boiling point & $2980^{\circ} \mathrm{C}$ \\
\hline Density & $3.9 \mathrm{~g} / \mathrm{cm}^{3}$ \\
\hline
\end{tabular}

TABLE 3: Specifications of the OROTECH exhaust gas analyser TABULKA 3: Specifikace analyzátoru výfukových plynů OROTECH

\begin{tabular}{lcc} 
Measurement Parameters & Range & Resolution \\
\hline Carbon monoxide (CO) & $0-10 \%$ vol. & $0.001 \%$ vol. \\
\hline Hydrocarbon $(\mathrm{HC})$ & $0-9999 \%$ ppm vol. & $1.0 \mathrm{ppm}$ vol. \\
\hline Oxides of nitrogen $\left(\mathrm{NO}_{\mathrm{x}}\right)$ & $0-5000 \mathrm{ppm}$ vol. & $1.0 \mathrm{ppm}$ vol.
\end{tabular}

TABLE 4: Specification of the AVL437C smoke meter TABULKA 4: Specifikace kouřoměru AVL437C

\begin{tabular}{|c|c|c|}
\hline Measurement Parameters & Range & Resolution \\
\hline Opacity & 0-99.9\% & $0.1 \%$ \\
\hline Linearity & $\pm 0.1 \mathrm{~m}^{-1}$ & \\
\hline Repeatability & $\pm 0.1 \mathrm{~m}^{-1}$ & \\
\hline Response time- physical & $<0.4$ seconds & \\
\hline Response time- electrical & $<1$ millisecond & \\
\hline $\begin{array}{l}\text { Warm up time at atm. } \\
\text { conditions }\end{array}$ & $<7$ minutes & \\
\hline Engine RPM & 400-9990 RPM & 10 RPM \\
\hline Engine oil temperature & $0-150^{\circ} \mathrm{C}$ & $1{ }^{\circ} \mathrm{C}$ \\
\hline Operating temperature & $5^{\circ} \mathrm{C}$ to $50^{\circ} \mathrm{C}$ & \\
\hline Smoke measuring cell length & $\begin{array}{l}215 \mathrm{~mm} \text { (430mm } \\
\text { folded length) }\end{array}$ & \\
\hline
\end{tabular}

of 1500 RPM. The engine was initially hand cranked with a pure diesel supply to bring it to a steady state. The engine was coupled to an eddy current dynamometer that allowed varying of the engine load from no-load to full load. The engine test rig was computerized and both the engine and dynamometer were interfaced to a control panel in a computer. The computer had 'Engine Analysis Software' which recorded test parameters such as temperature, air flow rate, fuel flow rate, load etc. It also plotted the engine performance characteristics such as brake thermal efficiency, heat release rate etc. The load was varied in four steps from no-load to full load. The engine was run with B20PLOME, B20PLOME30A and B20PLOM30A15E whilst keeping all the above conditions constant. The performance, combustion and emissions tests were carried out. An OROTECH Exhaust Gas Analyzer, as specified in Table 2, was used for exhaust gas analysis. The AVL437C Smoke Meter, as specified in Table 3, was used for recording smoke opacity.

\subsection{UNCERTAINTY ANALYSIS}

The uncertainties of the parameters are calculated by sequential perturbation. The average uncertainties of measured and calculated parameters are air flow rate $(1.1 \%)$, liquid fuel flow rate $(0.1 \%)$, gas flow rate $(2 \%)$, engine load $(0.1 \%)$, engine speed $(1.3 \%)$, cylinder pressure $(0.8 \%)$, temperature $(1.0 \%)$ and LCV of liquid fuel $(1.0 \%)$. Based on these, the calculated accuracy of the performance and combustion studies of the engine is found to be within $\pm 4.6 \%$. However, the accuracy of the emission study is found to be $\pm 4.6 \%$. The maximum values of coefficient of variance (COV) of the performance parameters, viz., BTE and BSFC are 3 and $4 \%$ respectively. Whereas, the combustion emission parameters, namely Peak Cylinder Pressure, Ignition Delay, $\mathrm{CO}, \mathrm{HC}$ and $\mathrm{NO}_{\mathrm{x}}$ are shown to have COVs of 5, 4, 2, 2 and $6 \%$ respectively.

\section{RESULTS AND DISCUSSION}

\subsection{PERFORMANCE CHARACTERISTICS \\ 4.1.1 BRAKE THERMAL EFFICIENCY}

Figure 3 shows the variation of BTE with load. The BTE of all the blends increased as load increases. The maximum load on the engine was $30 \mathrm{Nm}$ of torque and the brake mean effective pressure at maximum load was 4 bar. The B2OPLOME blend showed an increase in BTE due to better combustion. This is due to the oxygen content within the methyl ester. The addition of nanoparticles (B20PLOME30A) further improved BTE because of the enhanced surface area to volume ratio, which leads to more fuel reacting with air causing rapid evaporation and combustion. B20PLOME30A15E blend showed a further increase in the combustion efficiency due to additional oxygen content from 


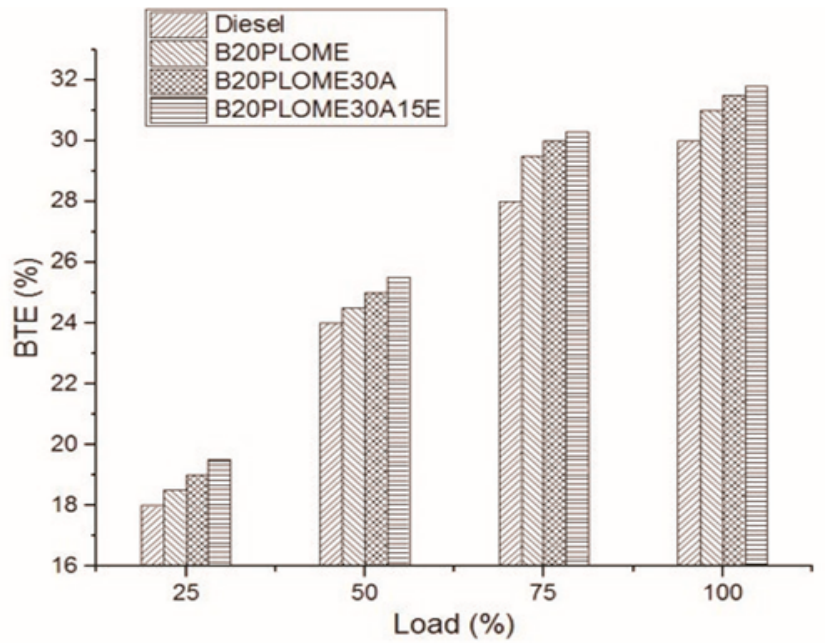

FIGURE 3: Variation of BTE with load

OBRÁZEK 3: Změna tepelné účinnosti v závislosti na zátěži

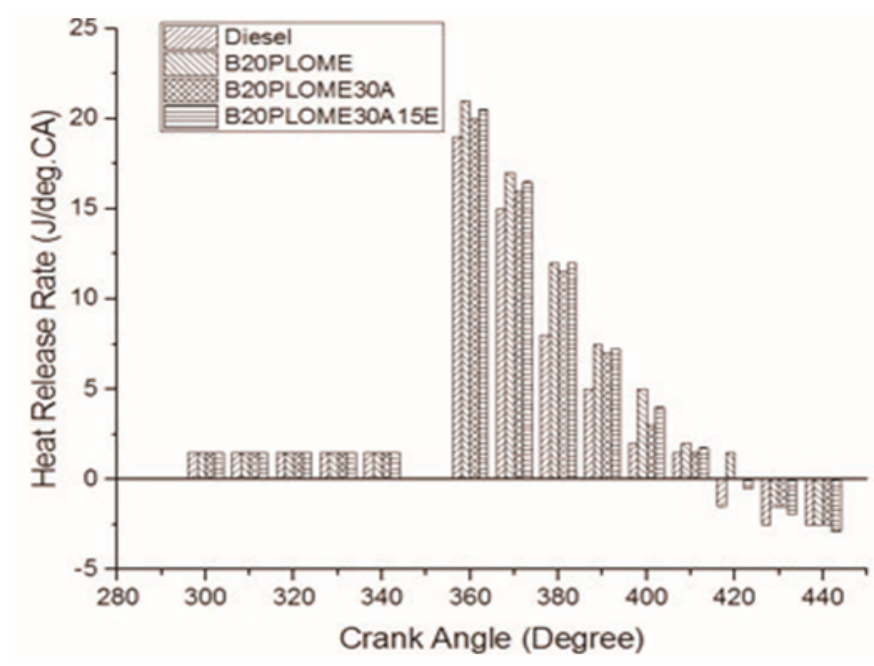

FIGURE 5: Variation of HRR with crank angle

OBRÁZEK 5: Změna HRR v závislosti na poloze klikového hřídele

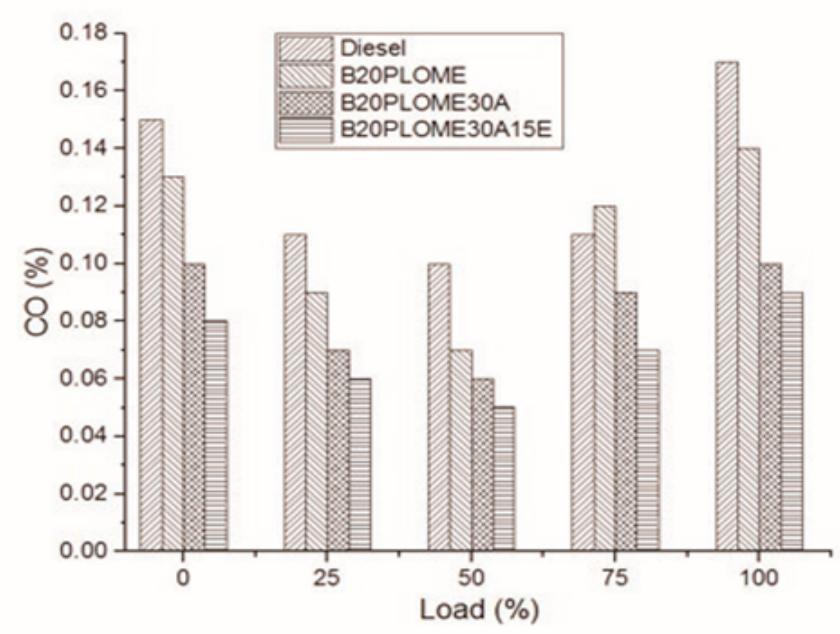

FIGURE 7:Variation of CO with load

OBRÁZEK 7: Změna emisí CO v závislosti na zátěži

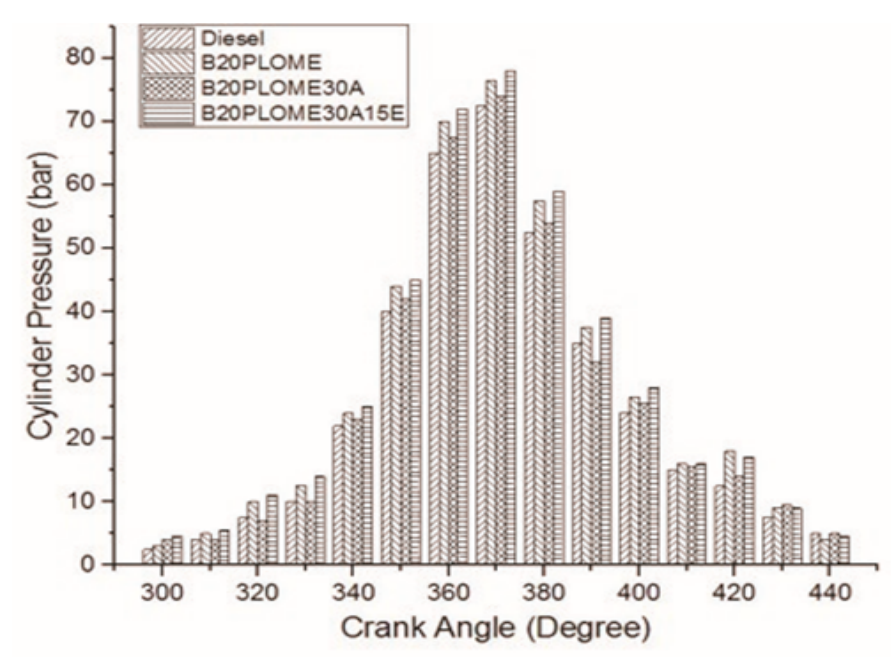

FIGURE 4: Variation of cylinder pressure with crank angle OBRÁZEK 4: Změna tlaku ve válci v závislosti na natočení klikového hř́dele

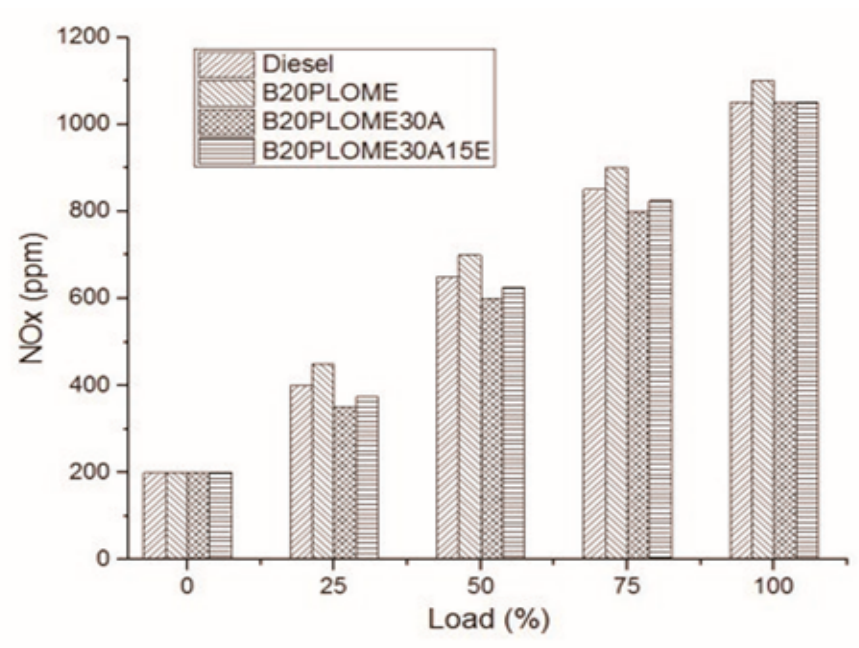

FIGURE 6: Variation of $\mathrm{NO}_{x}$ with load OBRÁZEK 6: Změna emisí $\mathrm{NO}_{x} v$ závislosti na zátěži

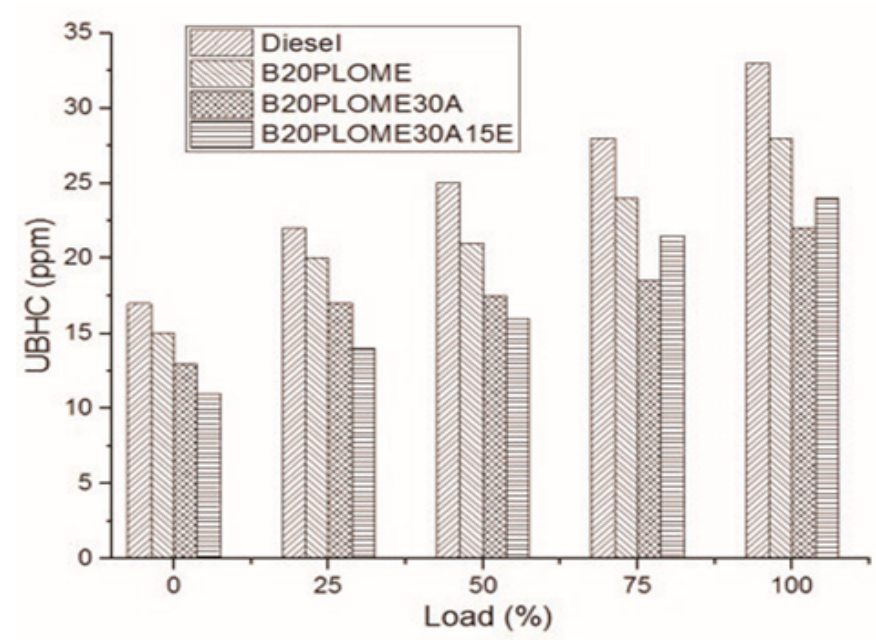

FIGURE 8: Variation of UBHC with load OBRÁZEK 8: Změna UBHC v závislosti na zátěži 
ethanol. Ethanol also decreased the density and viscosity of the fuel, which improved atomization.

\subsection{COMBUSTION CHARACTERISTICS}

\subsubsection{PEAK CYLINDER PRESSURE}

The variation of peak pressure displayed by the different fuels for various crank angles is shown in Figure 4. At full load, the peak pressure of B20PLOME was higher than that of diesel for all loads. This can be attributed to the longer ignition delay and higher oxygen content in the case of B20PLOME. At full load, B20PLOME30A showed higher peak pressure than pure diesel due to higher ignition delay and more complete combustion because of the improved surface area volume ratio. For B20PLOME30A15E, the combustion pressure increased due to better mixing of air and fuel, which resulted in better combustion, and the addition of ethanol results in a lower cetane number of the blend and hence longer ignition delay [6] (Krzysztof Gorski et al. 2011).

\subsubsection{HEAT RELEASE RATE}

Figure 5 shows the variation of HRR for various crank angles. B20PLOME displays a marginal increase in HRR when compared to diesel. At full load, HRR was slightly greater than diesel due to more oxygen molecules being present in B20PLOME than in diesel. B20PLOME30A shows a marginal increase in HRR compared to diesel because of better combustion, improved atomization and rapid evaporation. The HRR of B20PLOME30A was slightly lower than B20PLOME because the addition of nanoparticles causes advancement in combustion. B20PLOME30A15E showed higher HRR than B20PLOME30A because the longer ignition delay due to addition of ethanol causes rapid combustion in the premixed phase and results in an increase of HRR [12] (V. Arul MozhiSelvan et al. 2009).

\subsection{EMISSION CHARACTERISTICS}

\subsubsection{OXIDES OF NITROGEN}

Figure 6 shows the variation of $\mathrm{NO}_{x}$ for various loads. Atmospheric nitrogen is stable at normal temperature and pressure, and exists as a diatomic molecule. However, inside the engine cylinder, where it is subjected to high temperature and pressure, it reacts with oxygen to form various oxides. These are designated $\mathrm{NO}_{\mathrm{x}}$. $\mathrm{NO}_{x}$ formation is a strongly time and temperature dependent phenomena. $\mathrm{NO}_{x}$ emissions increased with increasing load for all fuels because as load increases, the temperature of the combustion chamber and rate at which temperature rises in the cylinder also increases. The HRR was high in the case of B2OPLOME as a result of the temperature inside cylinder increasing rapidly, thereby increasing $\mathrm{NO}_{x}$ emissions when compared to diesel. The $\mathrm{NO}_{x}$ emissions of B2OPLOME30A appear to decrease marginally compared to that of diesel, which was because the catalytic behaviour of nanoparticles promotes the reaction in the forward direction and form final products with the least thermal break down of the hydrocarbon compounds. The B20PLOME30A15E blend showed a marginal increase in $\mathrm{NO}_{x}$ emissions when compared to diesel. This can be attributed to the higher heat release rate of the B2OPLOME30A15E blend.

\subsubsection{CARBON MONOXIDE EMISSIONS}

Figure 7 shows the variation of $\mathrm{CO}$ emissions for various loads. $\mathrm{CO}$ emissions decreased at part load and again increased at full load conditions for all fuels. The B20PLOME blend showed a decrease in $\mathrm{CO}$ emissions when compared to diesel. This can be attributed to the higher oxygen content in the methyl esters. The catalytic behaviour of nanoparticles, improved ignition characteristics of alumina nanoparticles and the shortening of ignition delay further decreased the $\mathrm{CO}$ emissions of the B20PLOME30A blend when compared to the B20PLOME blend. The higher oxygen content of the B2OPLOME30A15E blend further promoted the oxidation of $\mathrm{CO}$ to $\mathrm{CO}_{2}$ and decreased $\mathrm{CO}$ emissions when compared to the B20PLOME blend [5] (K. Ramarao et al. 2015).

\subsubsection{UNBURNT HYDROCARBONS (UBHC)}

Figure 8 shows the variation of UBHC emissions for various loads. The UBHC emissions for all fuels increased with increasing load. UBHC emissions for all blends are lower than for diesel. At full load, B20PLOME, B20PLOME30A and B20PLOME30A15E showed respectively a $21.2 \%, 37.5 \%$ and $30.3 \%$ reduction in UBHC emissions when compared to diesel. The B20PLOME blend is comprised of animal fat oil methyl esters, i.e., it contains hydrocarbon chains whose one end of the chain is oxygenated. The presence of oxygen in biodiesel promotes combustion that leads to lowering the hydrocarbon emissions [10] (Senthil Kumar et al. 2001). The B20PLOME30A blend showed a further decrease in UBHC emissions, which can be attributed to the catalytic behaviour of alumina nanoparticles. The alumina nanoparticles were responsible for shortening the ignition delay and hence further reduced UBHC emissions [14] (Yetter R. et al. 2009). At lower loads the B20PLOME30A15E blend displayed a decrease in UBHC emissions when compared to B20PLOME30A. However, at loads above $50 \%$ an increase in UBHC emissions was observed when compared to B20PLOME30A. This is because of the lower combustion temperature caused by the higher latent heat of vaporisation of ethanol [4] (Hwanam Kim et al. 2010).

\subsubsection{SMOKE OPACITY}

Figure 9 shows the variation of smoke opacity with load. It was observed that the smoke opacity of exhaust gases increases with load for all fuels. Smoke emission is closely related to the ignition delay, volatility and fuel oxygen content. The extended ignition 


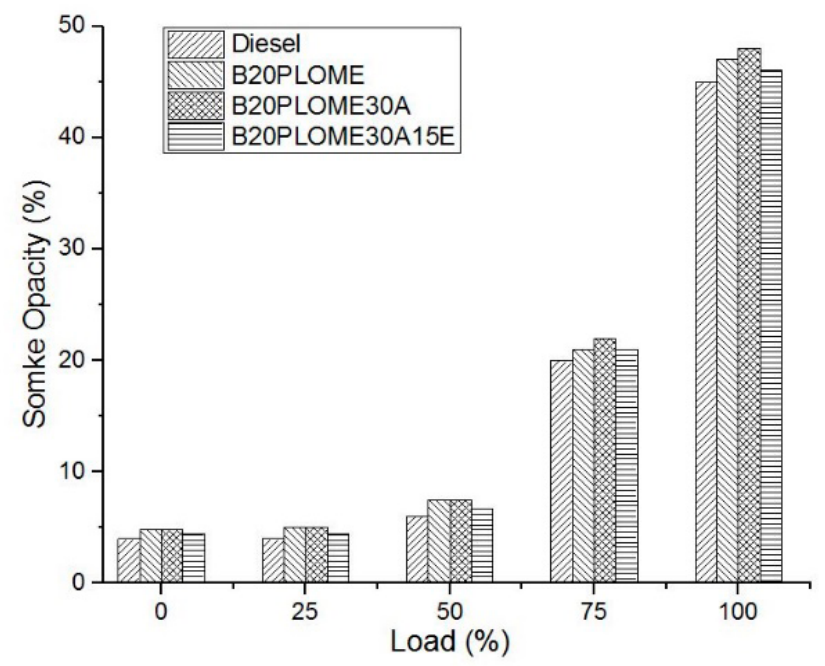

FIGURE 9: Variation of smoke opacity with load OBRÁzEK 9: Změna kouřivosti v závislosti na zátěži

delay and high volatility can improve the fuel-air mixing process, and the oxygen in fuel can reduce the formation of soot precursors and enhance soot oxidation [15] (Zunquing Zheng et al. 2016). Due to the higher viscosity of B20PLOME and B20PLOME30A, the volatility and air-fuel mixing of these blends was poor. Also, since the molecules of B2OPLOME and B20PLOME30A were heavier, they lead to an increase in smoke opacity of exhaust gases when compared to diesel [1] (Baluswamy T et al. 2007). It can be observed that the smoke opacity of B2OPLOME30A15E was marginally higher than that of diesel and lower than that of B20PLOME and B20PLOME30A. This is because adding ethanol to the blend increased the oxygen content and volatility and reduced soot precursor concentration [7] (M. Mofijur et al. 2015).

\section{CONCLUSION}

The engine tests were conducted with B2OPLOME, B20PLOME30A and B20PLOME30A15E from no load to full load conditions and the corresponding performance, combustion and emission characteristics were studied in comparison with diesel. The following results were observed - upon transesterification of poultry litter oil, it was observed that there was a reduction in kinematic viscosity and density whereas the calorific value was observed to increase. All the three blends showed increased BTE when compared to diesel. B20PLOME30A15E showed a 10.7\% increase in BTE when compared to diesel. The highest cylinder pressure was recorded for B20PLOME30A15E. The addition of ethanol increases the volatility and oxygen content, which promotes combustion and as a result a further reduction in $\mathrm{CO}$ emissions and smoke opacity were observed when compared to B2OPLOME and B2OPLOME30A. The addition of ethanol increases the ignition delay period, and as a result B20PLOME30A15E shows maximum peak cylinder pressure

and hence the $\mathrm{NO}_{x}$ emissions of $\mathrm{B} 20 \mathrm{PLOME} 30 \mathrm{~A} 15 \mathrm{E}$ were marginally higher than that of B2OPLOME30A. At $50 \%$ load, the UBHC emissions of B2OPLOME30A15E were marginally higher than that of B2OPLOME30A; this is due to higher latent heat of vaporisation of ethanol, which reduces the combustion temperature. This proves that poultry litter oil biodiesel with alumina nanoparticles and ethanol as an additive can be used as a renewable and environmentally friendly fuel, minimising the use of mineral diesel. Also, poultry litter oil can be utilized as a fuel through this waste management technique.

\section{LIST OF NOTATIONS AND ABBREVIATIONS \\ $\mathrm{Cl}$ \\ BTDC \\ $\mathrm{BP}$ \\ BTE \\ HRR \\ CO \\ $\mathrm{NO}_{\mathrm{x}}$ \\ UBHC \\ 02 \\ ppm \\ ASTM \\ PLOME \\ B20 \\ B2OPLOME \\ B20PLOME30A \\ Compression Ignition \\ Before Top Dead Centre \\ Brake Power \\ Brake Thermal Efficiency \\ Heat Release Rate \\ Carbon Monoxide \\ Oxides of Nitrogen \\ Unburnt Hydrocarbons \\ Oxygen \\ Parts per million \\ American Society for \\ Testing and Materials \\ Poultry Litter Oil Methyl Ester \\ $20 \%$ Biodiesel $+80 \%$ Diesel \\ $20 \%$ Poultry Litter Methyl Ester $+80 \%$ Diesel \\ $20 \%$ Poultry Litter Methyl Ester $+80 \%$ Diesel \\ $+30 \mathrm{mg} / \mathrm{l} \mathrm{AL2O3}$ \\ B20PLOME30A15E 20\% Poultry Litter Methyl Ester $+80 \%$ Diesel $+30 \mathrm{mg} / \mathrm{l} \mathrm{AL203}+15 \mathrm{ml}$ Ethanol/l}

\section{REFERENCES}

[1] Baluswamy T, Marappan R, Performance evaluation of direct injection diesel engine with blends of Thevetiaperuviana seed oil and diesel, Journal for Scientific and Industrial Research, Vol 66, December 2007, 1035-1040

[2] Darunde Dhiraj S., Prof. Deshmukh Mangesh M., Biodiesel Production from Animal Fats and Its Impact On the Diesel Engine with Ethanol-Diesel Blends: A Review, IJETAE, Vol 2, Issue 10, October 2012, ISSN 2250-2459

[3] Dr. Sadhik B. J., Anand, R. B. Effects of nanoparticle additive in the water diesel emulsion fuel on the performance, emission and combustion characteristics of a diesel engine, Journal of Vehicle Design, Vol 59, Issue 2/3, 164-181, 2012

[4] Hwanam Kim, Byungchul Choi, the effect of biodiesel and bioethanol blended diesel fuel on nanoparticles and exhaust emissions from CRDI diesel engine, Renewable Energy, 2010, Vol 35, Issue 1, 157-163 
[5] K. Ramarao, C. J. Rao , D. Sreeramulu, The Experimental Investigation on Performance and Emission Characteristics of a Single Cylinder Diesel Engine using Nano Additives in Diesel and Biodiesel, Indian Journal of Science and Technology, Vol 8, Issue 29, November 2015

[6] Krzysztof Gorski, Ruslands Smigins, Impact of ether/ ethanol and biodiesel blends on combustion process of compression ignition engine, Engineering for Rural Development, Jelgava, 26, 2011.

[7] M. Mofijur, M.G. Rasul, J. Hyde, Recent developments on internal combustion engine performance and emissions fuelled with biodiesel-diesel-ethanol blends, Procedia Engineering, Vol 105, 2015, 658-664

[8] Nithin Samuel, Muhammed Shefeek K, Performance and Emission Characteristics of a C.I. Engine with Cerium Oxide Nanoparticles as Additive to Diesel, IJSR, Vol 4, Issue 7, July 2015, ISSN (Online): 2319-7064

[9] S.P. Venkatesan, Kadiresh PN, Influence of Aluminum Oxide Nanoparticle Additive on Performance and Exhaust Emissions of Diesel Engine, IJAER, Vol 10, Issue 3, Jan 2015, 5741-5749

[10] Senthil Kumar, Ramesh A and Nagalingam B, Experimental investigation on Jatropha oil-Methanol duel fuel engine, SAE Technical Paper, Vol 0153, Issue 01, 2001
[11] Sri Harsha Tirumala, A.V.Rohit, Siva Krishna.M, SudiptaSaha, Synthesis of neem biodiesel, IJAET, Vol 3, Issue 1, January-March, 2012, 316-318, E-ISSN 0976-3945

[12] V. Arul MozhiSelvan, R. B. Anand and M. Udayakumar, Effects of cerium oxide nanoparticle addition in diesel and diesel-biodiesel-ethanol blends on the performance and emission characteristics of a $\mathrm{Cl}$ engine, ARPN Journal of Engineering and Applied Sciences, Vol 4, Issue 7, September 2009, ISSN 1819-6608

[13] Xiaoyan Shi, Xiaobing Pang, Yujing Mu, Hong He, Shijin Shuai, Jianxin Wang, Hu Chen, Rulong Li, Emission reduction potential of using ethanol-biodiesel-diesel fuel blend on a heavy-duty diesel engine, Atmospheric Environment, Vol 40 Issue 14, May 2006, 2567-2574

[14] Yetter R. A., Grant A R, Steven F S, Metal particle combustion and nanotechnology, Proceedings of the Combustion Institute 2009, Vol 32, Issue 2, 1819-1838

[15] Zunquing Zheng, Xiaofeng Wang, Xiaofan Zhong, Bin Hu, Haifeng Liu, Mingfa Yao, Experimental study on the combustion and emission fuelling biodiesel/n-butanol, biodiesel/ethanol, and biodiesel/2,5-dimethylfuran on a diesel engine, Elsevier Energy, Vol 115, Issue 1, November 2016, 539-549 